\title{
DINAMIKA SPREMINJANJA KATEGORIJ POSELITVENE RABE ZEMLJIŠČ V SLOVENIJI V OBDOBJU I991-2002
}

Projekt »Dinamika spreminjanja kategorij poselitvene rabe zemljišč v Sloveniji v obdobju 1991-2002« je naročilo in v celoti financiralo Ministrstvo za okolje, prostor in energijo. Nosilec leto in pol trajajoče raziskave v letih 2003-2004, je bil Marko Krevs z Oddelka za geografijo Filozofske fakultete Univerze v Ljubljani. Pri njeni izvedbi je sodelovalo nekaj mladih sodelavcev oddelka (Blaž Repe, Dejan Cigale, Barbara Lampič, Andrej Herakovič), študentov geografije in zunanji sodelavec Andrej Grilc.

Naročnik raziskave je za oceno dinamike oziroma različnih vidikov prostorskih sprememb kategorij poselitvene rabe zemljišč potreboval primerljive bilance poselitvenih kategorij zemljišč (poselitvene rabe zemljišč) v Sloveniji za vsaj dva časovna prereza v obdobju med letoma 1991 in 2002 . Naloga bi bila relativno preprosta, če bi obstajal vir podatkov, ki bi za vsaj dva časovna prereza v omenjenem obdobju omogočal prostorsko in vsebinsko točno predstavitev poselitvene rabe zemljišč. »Idealen« temeljni vir podatkov za omenjeno nalogo bi bil lokacijsko in vsebinsko (z vidika kategorij rabe zemljišč) kakovosten ter ažuren digitalni zemljiški kataster, dopolnjen s prav tako kakovostnim katastrom stavb. Žal oba vira nista ustrezala zgoraj navedenim zahtevam.

Glavni namen raziskave je bil preveriti in dopolniti dosedanja spoznanja o spreminjanju poselitvene rabe zemljišč v obravnavanem obdobju na podlagi številnih dostopnih zbirk podatkov ter $\mathrm{s}$ tem prispevati k naporom ministrstva za oblikovanje Programa ukrepov zemljiške politike.

Raziskava je bila z vidika količine in raznovrstnosti uporabljenih zbirk podatkov izredno obsežna in delovno intenzivna. Pokazala je, da velika količina različnih zbirk podatkov ne zagotavlja možnosti za ustrezno kakovostno spremljanje spreminjanja poselitvene rabe tal. V času izvedbe raziskave je bil edini vir, ki je vsaj deloma omogočal ocenjevanje sprememb v poselitveni rabi tal po statističnih regijah v Sloveniji, Statistični GIS pokrovnosti in rabe tal Slovenije za leta 1993, 1997 in 2001. Žal tudi ta tri stanja »pokrovnosti in rabe tal« zaradi metodoloških in tehničnih razlogov niso povsem primerljiva, zato smo se morali zadovoljiti zgolj z relativno grobimi ocenami sprememb poselitvene rabe tal po statističnih regijah.

Med pomembna spoznanja $\mathrm{v}$ raziskavi poleg omenjenih ocen uvrščamo ugotovitve o kakovosti podatkov in njihovi primernosti za nadaljnje proučevanje poselitvene rabe zemljišč ter njene dinamike. Med »dodatnimi« cilji smo morda najuspešneje zasledovali opredeljevanje območij strnjene in razpršene poselitve, saj so analize potrdile, da se na teh območjih odvijajo zelo različni in tudi različno intenzivno procesi spreminjanja poselitvene rabe zemljišč. Podobno zanimiva so spoznanja o spreminjanju kategorij poselitvene rabe zemljišč z oddaljevanjem od večjih (makro in mezoregionalnih) središč, ter po različno urbaniziranih območjih.

Med izvajanjem raziskave smo le utrdili prepričanje, da bi z vidika podatkov o (poselitveni) rabi zemljišč in seveda $z$ vidika razlogov, da se ti podatki sploh zbirajo, moral biti primarni cilj države izboljšanje kakovost podatkov v že obstoječih ali nastajajočih registrih 
oziroma katastrih, zlasti v zemljiškem katastru in katastru stavb. Omenjena nekakovost je namreč glavni razlog, da omenjenih katastrov ne uporabljamo kot verodostojnega vira za ugotavljanje rabe tal. Po našem mnenju tudi po pričakovanem izboljšanju nepremičninskih evidenc ne bo mogoče opustiti drugih virov, zlasti daljinsko zaznanih podatkov, vendar bi moral postati glavni namen njihove uporabe preverjanje ali dopolnjevanje podatkov v katastrih, in ne uporaba kot temeljnega vira o rabi zemljišč.

Vmesni in končni rezultati raziskave so bili predstavljeni na simpoziju »Remote sensing of urban areas« v Regensburgu leta 2003, mednarodni delavnici »Applicability of remote sensing in research of urban landuse « leta 2003 v Ljubljani, znanstvenem seminarju »Geografska problematika Ljubljane in Zagreba« leta 2004 v Ljubljani, Zborovanju slovenskih geografov leta 2004 v Velenju, ter objavljeni v zborniku omenjenega simpozija v Regensburgu, v publikaciji »GIS v Sloveniji 2003-2004« ter v reviji Dela 22.

Marko Krevs 